\title{
Effects of nitrogen dioxide exposure and ascorbic acid supplementation on exhaled nitric oxide in healthy human subjects
}

\author{
D C Chambers, J G Ayres
}

\begin{abstract}
Background-Nitric oxide (NO) is detectable in the exhaled breath, is involved in airway defence and inflammation, and probably modulates bronchial smooth muscle tone. Given the sensitivity of nitrogen oxides to local redox conditions, we postulated that exposure to oxidant or antioxidant compounds could alter concentrations of NO in the exhaled breath (eNO). We assessed the effect of nitrogen dioxide $\left(\mathrm{NO}_{2}\right)$ and ascorbic acid exposure on eNO in healthy human subjects.

Methods-Ten healthy subjects were randomised to undergo a 20 minute single blind exposure to $\mathrm{NO}_{2}(1.5$ parts per million) or medical air in a crossover fashion. Exhaled NO and pulmonary function were measured before and for 3 hours after exposure. In a separate double blind crossover study 20 healthy subjects received ascorbic acid $500 \mathrm{mg}$ twice daily or placebo for 2 weeks with a 6 week interim washout. Serum ascorbic acid levels and eNO were measured before and after each supplementation phase.

Results- $\mathrm{NO}_{2}$ induced a decrease of 0.62 $(95 \% \mathrm{CI} 0.32$ to 0.92$) \mathrm{ppb}$ in the mean post-exposure eNO $(p<0.01)$ with no change in forced expiratory volume in 1 second $\left(\mathrm{FEV}_{1}\right)$. Oral supplementation with ascorbic acid increased the mean serum ascorbic acid concentration by 7.4 (95\% CI 5.1 to 9.7$) \mu \mathrm{g} / \mathrm{ml}(63 \%)$ but did not alter eNO.

Conclusions- $\mathrm{NO}_{2}$ exposure causes a decrease in eNO, an effect which may be mediated through changes in epithelial lining fluid redox state or through a direct effect on epithelial cells. In contrast, ascorbic acid does not appear to play a significant role in the metabolism of $\mathrm{NO}$ in the epithelial lining fluid.

(Thorax 2001;56:774-778)
\end{abstract}

Heartlands Research Institute, Birmingham Heartlands Hospital, Birmingham B9 5SS, UK

D C Chambers

J G Ayres

Correspondence to: Professor J G Ayres ayresj@heartsol.wmids.nhs.uk

Received 15 January 2001 Accepted for publication 25 July 2001 reactive molecule with many potential target molecules in the airway wall and in the epithelial lining fluid (ELF). ${ }^{2}$ Concentrations of NO gas in the airway lumen may therefore not only reflect changes in NOS activity or induction, but also changes in local airway chemistry.

A precedent for this suggestion can be found in the systemic vasculature where $\mathrm{NO}$ is the predominant endothelium derived relaxing factor. In this environment, NO has a very short half life due to its rapid reaction with superoxide, ${ }^{3}$ and its activity is modified by the antioxidant ascorbic acid. ${ }^{4}$

In the lung there is already evidence that eNO is affected by changes in airway chemistry. Patients with cystic fibrosis do not have increased eNO levels despite the severity of their airway inflammation, but they do have increased levels of nitrite, the stable end product of NO autoxidation, in breath condensate. ${ }^{6}$ These findings suggest that, although NOS activity is increased in this patient group, NO undergoes autoxidation before passing into the lumen. Changes in airway chemistry have been postulated to alter eNO in asthma as well. The $\mathrm{pH}$ of breath condensate is lower in patients with asthma ${ }^{7}$ and, since $\mathrm{NO}$ metabolism is $\mathrm{pH}$ sensitive, this may help to explain the increase in eNO found in asthmatic subjects. ${ }^{8}$

The aim of the studies presented here was to determine if eNO is altered by exposure to oxidants (nitrogen dioxide $\left(\mathrm{NO}_{2}\right)$ ) and antioxidants (ascorbic acid) in healthy human subjects. Ascorbic acid was chosen for the antioxidant exposure because of its known effects on the chemistry of NO in the systemic vasculature. ${ }^{4}{ }^{5} \mathrm{NO}_{2}$ was chosen for the oxidant exposure as this oxidising gas is known to undergo reactive absorption and then to alter ELF redox state in the airway ELF in a predictable and reproducible fashion following inhalation. $^{9} 10$

\section{Methods}

STUDY DESIGN

Given that the intra-individual standard deviation in eNO in healthy volunteers is approximately 0.8 parts per billion ( $\mathrm{ppb}$ ) while the inter-individual standard deviation is approximately $3 \mathrm{ppb}$ (data from previous work in our laboratory), paired designs were chosen to increase the power of the studies. For the ascorbic acid study, in order to have an $80 \%$ chance of detecting a $1 \mathrm{ppb}$ difference in eNO between active and placebo supplementation at the 0.05 significance level with a standard deviation of $0.8 \mathrm{ppb}, 20$ subjects were required. The summation of serial measures used 
to assess eNO in the $\mathrm{NO}_{2}$ study (see statistics section) should lead to a smaller intraindividual standard deviation, so only 10 subjects were recruited to undergo $\mathrm{NO}_{2}$ exposure.

\section{SUBJECTS}

Healthy non-smoking subjects not taking nutritional supplements were screened. Those with spirometric evidence of airway obstruction, those with known respiratory disease, and those taking glucocorticoid medication were excluded. Subjects who had participated in one study were not considered for participation in the other.

PROTOCOL

$\mathrm{NO}_{2}$ exposure

Exposures with medical air and $\mathrm{NO}_{2} 1.5$ parts per million (ppm), each for 20 minutes at rest were carried out at the same time of day on separate days with an interval of at least 1 week in a single blind, randomised, placebo controlled, crossover fashion.

The exposure system has been previously described. ${ }^{11}$ Briefly, subjects sit, resting comfortably, with the head enclosed in a perspex dome, while medical air is delivered at $120 \mathrm{l} / \mathrm{min}$ by means of an in-series mass flow controlled valve $(5853 \mathrm{E}$, Brooks Instruments, Netherlands). $\mathrm{CO}_{2}$ concentrations in the dome are monitored during exposure and nose clips are not used. For the $\mathrm{NO}_{2}$ exposure, $\mathrm{NO}_{2}$ in nitrogen (60 ppm, British Oxygen Company) was blended via another mass flow controlled valve (5850S, Brooks Instruments) in a ratio of 1:40 to obtain a final concentration for $\mathrm{NO}_{2}$ of $1.5 \mathrm{ppm}$. The final concentration was checked before all exposures using an $\mathrm{NO}_{2}$ analyser (PrinterNOx, Micro Medical Ltd, Kent, UK) sensitive to $0.05 \mathrm{ppm}$. Before exposure, eNO levels were measured five times and the mean was taken as the baseline eNO level, and spirometric tests were performed (Vitalograph Compact, Vitalograph Ltd, Buckingham, UK) to obtain the best $\mathrm{FEV}_{1}$ and forced vital capacity (FVC) from at least two exhalations within $5 \%$. After exposure, eNO levels were measured in triplicate and $\mathrm{FEV}_{1}$ was recorded at each of $0,5,10,15,30,45,60,90,120,150$, and 180 minutes. Spirometric tests were always performed after eNO assessment.

\section{Ascorbic acid supplementation}

This study was also performed in a randomised, placebo controlled, crossover fashion but the supplementation in this case was double blind. The study design was based on the pharmacokinetic data obtained for ascorbic acid by Levine et al who showed that $1000 \mathrm{mg} /$ day ascorbic acid would be expected approximately to double serum concentrations of ascorbic acid without significant risk of toxicity. ${ }^{12} 13$ Two supplementation phases, each of 2 weeks, were separated by a 6 week washout phase. Subjects continued to consume their normal diet during the study. During the active phase subjects consumed ascorbic acid $500 \mathrm{mg}$ morning and night and during the placebo phase they consumed an identical looking and tasting placebo (Quest Vitamins Ltd, Birmingham, UK). Compliance was checked by pill counts at the end of each supplementation phase. eNO was assessed as the mean of five measurements before and after each supplementation phase, and venous blood was drawn for the estimation of serum ascorbic acid concentrations.

For the serum ascorbic acid assay, $1 \mathrm{ml}$ of serum was combined with $1 \mathrm{ml} 10 \%$ metaphosphoric acid, prepared fresh daily, and centrifuged at $3000 \mathrm{rpm}$ for 6 minutes. The supernatant was then stored at $-70^{\circ} \mathrm{C}$ until analysed. The assay was performed using a highly sensitive high performance liquid chromatographic method. ${ }^{14}$ Ascorbic acid concentrations are expressed in $\mu \mathrm{g} / \mathrm{ml}$. The normal range in healthy individuals is diet dependent, but is usually $>4 \mu \mathrm{g} / \mathrm{ml}^{13}$

\section{ENO ASSESSMENT}

eNO was measured by chemiluminescence (LR2000, Logan Research, Kent, UK) in accordance with European Respiratory Society and American Thoracic Society guidelines. ${ }^{15} 16$ Briefly, subjects inhaled to total lung capacity and then completed a slow vital capacity exhalation through a resistance with a flow meter in series. A visual feedback display allowed the subject to maintain a flow rate of approximately $200 \mathrm{ml} / \mathrm{s}$ during the exhalation while the resistance maintained soft palate closure. Nose clips were not used. The chemiluminescence analyser sampled the exhalate in real time at $250 \mathrm{ml} / \mathrm{min}(4.2 \mathrm{ml} / \mathrm{s})$ with a sensitivity of $0.3 \mathrm{ppb}$ and a sampling rate of $25 \mathrm{~Hz}$. Calibration was performed daily and eNO levels were obtained from the plateau phase of the exhalation curve.

\section{STATISTICAL ANALYSIS}

Parametric statistics have been used throughout since eNO is normally distributed. For both studies data were analysed using change from baseline during each treatment period. For the $\mathrm{NO}_{2}$ study the serial eNO measurements after exposure were summarised for each individual using the area under the curve method, ${ }^{17}$ and the change from baseline levels was then calculated. For both studies FEV was $_{1}$ expressed as percentage predicted. Data for each study were first assessed for period and order effects. Mean changes in eNO $(\Delta \mathrm{eNO})$ and serum ascorbic acid concentrations $(\Delta$ Vit C) after exposure are presented with $95 \%$ confidence intervals and have been assessed for statistical significance using paired $t$ tests.

Both studies were approved by the East Birmingham Health Authority research and ethics committee.

\section{Results}

$\mathrm{NO}_{2}$ EXPOSURE

Ten subjects were screened and all completed the study. There was no statistically significant period or order effect, so data have been combined for analysis. The individual data are presented in table 1. Exposure to $\mathrm{NO}_{2}$ induced a mean fall in eNO levels of $0.62(95 \%$ CI 0.32 to 0.92$) \mathrm{ppb}$ while exposure to medical air 
Table 1 Baseline data and change in eNO ( $\triangle e N O$, parts per billion) following exposure for 20 minutes to placebo (medical air) or to NO ${ }_{2}$ (1.5 parts per million) in 10 healthy subjects

\begin{tabular}{|c|c|c|c|c|c|c|c|}
\hline \multirow[b]{2}{*}{ Subject no } & \multirow[b]{2}{*}{ Age } & \multirow[b]{2}{*}{ Sex } & \multirow[b]{2}{*}{$F E V_{1}(\%$ pred $)$} & \multicolumn{2}{|l|}{ Placebo exposure } & \multicolumn{2}{|l|}{$\mathrm{NO}_{2}$ exposure } \\
\hline & & & & Baseline eNO (ppb) & $\Delta e N O(p p b)$ & Baseline eNO (ppb) & $\triangle e N O(p p b)$ \\
\hline 1 & 26 & $\mathrm{~F}$ & 90 & 3.8 & 0.14 & 6.1 & -0.75 \\
\hline 2 & 30 & M & 93 & 10.5 & -0.62 & 9.2 & -0.98 \\
\hline 3 & 37 & $\mathrm{~F}$ & 82 & 4.5 & 0.58 & 7.3 & -1.41 \\
\hline 4 & 51 & $\mathrm{~F}$ & 90 & 3.5 & 0.56 & 4.1 & -0.21 \\
\hline 5 & 36 & $\mathrm{~F}$ & 90 & 7.3 & -0.49 & 7.2 & -0.66 \\
\hline 6 & 34 & M & 113 & 7.4 & 0.37 & 7.6 & -0.22 \\
\hline 7 & 28 & M & 106 & 10.2 & -1.11 & 9.4 & -0.58 \\
\hline 8 & 35 & $\mathrm{~F}$ & 86 & 3.3 & 0.97 & 4.6 & -0.72 \\
\hline 9 & 51 & $\mathrm{~F}$ & 105 & 3.4 & 0.81 & 4.4 & -0.74 \\
\hline 10 & 23 & $\mathrm{~F}$ & 85 & 9.1 & 1.63 & 11.2 & 0.06 \\
\hline Mean $(95 \% \mathrm{CI})$ & 35.1 & & 94 & 6.3 & $0.28(-0.30$ to 0.86$)$ & 7.1 & $-0.62^{\star}(-0.32$ to -0.92$)$ \\
\hline
\end{tabular}

$\Delta \mathrm{eNO}$ is calculated from the pre-exposure baseline eNO level and the post-exposure area under the eNO $v$ time curve. ${ }^{17}$ ${ }^{\star} \mathrm{p}<0.01$ compared with placebo.

produced no significant change in eNO $(0.28$ $(-0.3$ to 0.86$) \mathrm{ppb})$. The reduction in eNO following exposure to $\mathrm{NO}_{2}$ was statistically significant compared with placebo exposure $(\mathrm{p}<0.01)$ and fig 1 suggests that the reduction occurred between 60 minutes and 3 hours after

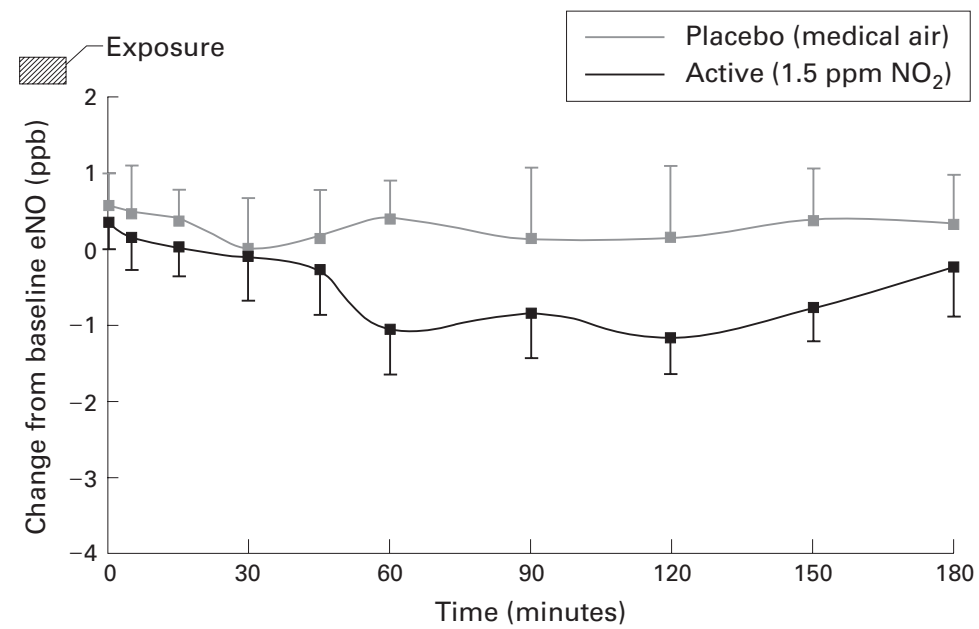

Figure 1 Mean (95\% confidence interval) change from baseline exhaled NO level ( $p p b$ ) at each time point following 20 minutes exposure to placebo (medical air) or $\mathrm{NO}_{2}$ (1.5 ppm) in 10 subjects. Time $0=$ end of exposure period. exposure. There was no statistically significant change in $\mathrm{FEV}_{1}$ (\% predicted) with $\mathrm{NO}_{2}$ exposure compared with placebo exposure.

ASCORBIC ACID SUPPLEMENTATION

Twenty five subjects were screened for inclusion. One subject was excluded because of evidence of airways obstruction and four did not complete the study (two non-compliant, one inadvertently commenced additional nutritional supplements, and one unable to attend clinic visits), leaving 20 subjects for study. The serum ascorbic acid concentration following placebo was unavailable for one subject. There was no statistically significant period or order effect, so data have again been combined for analysis. Individual data are presented in table 2. Ascorbic acid supplementation significantly increased the serum ascorbic acid concentration by 7.4 (95\% CI 5.1 to 9.7$) \mu \mathrm{g} / \mathrm{ml}(63 \%)$. Placebo supplementation did not significantly alter serum ascorbic acid concentrations. There was no significant change in eNO levels after either active or placebo supplementation (mean change in eNO 0.3 ( -0.6 to 1.2$) \mathrm{ppb}$ after ascorbic acid and -0.7 ( -1.7 to 0.3$) \mathrm{ppb}$ after placebo).

Table 2 Baseline data, change in eNO (4eNO, parts per billion) and change in serum ascorbic acid ( $\Delta$ Vit $C, \mu g / m l)$ following placebo or active (500 mg ascorbic acid bd) oral supplementation ( $n=20)$

\begin{tabular}{|c|c|c|c|c|c|c|c|c|c|c|c|}
\hline \multirow[b]{2}{*}{ Subject no } & \multirow[b]{2}{*}{ Age } & \multirow[b]{2}{*}{ Sex } & \multirow[b]{2}{*}{$\begin{array}{l}F E V_{1}(\% \\
\text { predicted) }\end{array}$} & \multicolumn{4}{|c|}{ Placebo exposure } & \multicolumn{4}{|c|}{ Ascorbic acid exposure } \\
\hline & & & & $\begin{array}{l}\text { Baseline } \\
\text { eNO (ppb) }\end{array}$ & $\begin{array}{l}\triangle e N O \\
(p p b)\end{array}$ & $\begin{array}{l}\text { Baseline Vit } \\
C(\mu g / m l)\end{array}$ & $\begin{array}{l}\Delta \text { Vit C } \\
(\mu g / m l)\end{array}$ & $\begin{array}{l}\text { Baseline } \\
\text { eNO }(p p b)\end{array}$ & $\begin{array}{l}\triangle e N O \\
(p p b)\end{array}$ & $\begin{array}{l}\text { Baseline Vit } \\
C(\mu g / m l)\end{array}$ & $\begin{array}{l}\Delta V i t C \\
(\mu g / m l)\end{array}$ \\
\hline 1 & 50 & $\mathrm{~F}$ & 92 & 4.3 & 0.1 & 12.4 & 0.9 & 2.9 & 0.8 & 11 & 11.1 \\
\hline 2 & 36 & $\mathrm{~F}$ & 85 & 6.2 & 0.7 & 11.0 & 0.1 & 4.5 & 4 & 11.7 & 7.5 \\
\hline 3 & 20 & $M$ & 100 & 7.1 & -0.2 & 11.6 & -0.6 & 5.6 & 0.1 & 11.3 & 11.9 \\
\hline 4 & 24 & M & 101 & 12.3 & -3.7 & 11.9 & 2.2 & 4.9 & 2.6 & 15 & 5.3 \\
\hline 5 & 47 & $\mathrm{~F}$ & 94 & 3.4 & 1.0 & 14.3 & -1.3 & 3.2 & 0.2 & 15.4 & 3.2 \\
\hline 6 & 35 & $\mathrm{~F}$ & 84 & 11.4 & -5.3 & 11.0 & & 7.4 & -0.3 & 13.4 & 5.1 \\
\hline 7 & 39 & $\mathrm{~F}$ & 103 & 11.9 & -2.3 & 15.1 & -0.8 & 9.8 & 0.3 & 13.4 & 11.9 \\
\hline 8 & 29 & $\mathrm{~F}$ & 87 & 7.9 & -0.3 & 9.4 & 1.7 & 8.2 & -1.7 & 11.8 & 1.8 \\
\hline 9 & 38 & $\mathrm{~F}$ & 92 & 8.8 & -1.4 & 9.2 & 0.4 & 11.4 & -1.2 & 10.1 & 12.7 \\
\hline 10 & 41 & $\mathrm{~F}$ & 93 & 9.2 & -3.2 & 16.3 & -3.3 & 7.3 & 0.3 & 12.6 & 8.1 \\
\hline 11 & 35 & $\mathrm{~F}$ & 112 & 5.4 & -1.9 & 14.8 & -1.3 & 3.2 & 0.8 & 15.8 & 1.8 \\
\hline 12 & 25 & $\mathrm{~F}$ & 80 & 2.9 & 2.1 & 9.7 & 2.9 & 6.3 & -1 & 11.9 & 4.2 \\
\hline 13 & 28 & $\mathrm{~F}$ & 105 & 5.8 & -0.5 & 11.7 & -3.3 & 7.2 & 0.1 & 4.6 & 22 \\
\hline 14 & 27 & $\mathrm{~F}$ & 96 & 3 & 1.4 & 9.9 & 2.9 & 6.5 & 1.8 & 12.5 & 6.8 \\
\hline 15 & 31 & $M$ & 96 & 5.4 & 2.3 & 13.3 & -1 & 5.3 & 3.4 & 11.1 & 6.6 \\
\hline 16 & 28 & M & 94 & 6.6 & 0.5 & 9.3 & 0.4 & 9.5 & -0.2 & 10.1 & 3.4 \\
\hline 17 & 25 & $\mathrm{~F}$ & 86 & 12.4 & -3.9 & 18.8 & -1.1 & 10.4 & 2.3 & 14.7 & 8.5 \\
\hline 18 & 30 & $M$ & 81 & 6.8 & -0.6 & 12.7 & 0.4 & 7.5 & -4.1 & 12.3 & 8.9 \\
\hline 19 & 43 & $M$ & 92 & 6.3 & -0.6 & 1.1 & 0.3 & 5.4 & -0.6 & 3.8 & 5.3 \\
\hline 20 & 47 & $\mathrm{~F}$ & 92 & 4.1 & 2.1 & 10.8 & 0.9 & 7 & -1.8 & 11.4 & 2.5 \\
\hline $\begin{array}{l}\text { Mean }(95 \% \\
\text { CI) }\end{array}$ & 33.9 & & 93.2 & 7.1 & $\begin{array}{l}-0.7(-1.7 \\
\text { to } 0.3)\end{array}$ & 11.7 & $\begin{array}{l}0(-0.8 \text { to } \\
0.8)\end{array}$ & 6.7 & $\begin{array}{l}0.3(-0.6 \text { to } \\
1.2)\end{array}$ & 11.7 & $\begin{array}{l}7.4^{\star}(5.1 \text { to } \\
9.7)\end{array}$ \\
\hline
\end{tabular}

The serum ascorbic acid concentration following placebo was unavailable for one subject.

${ }^{\star} \mathrm{p}<0.01$ compared with placebo. 


\section{Discussion}

Exposure to the oxidising gas $\mathrm{NO}_{2}$ (1.5 ppm for 20 minutes) induces a small but statistically significant decrease in eNO which appears to occur 1-3 hours after exposure. These findings are in line with those of Olin et al who described a non-statistically significant decrease in eNO after exposure to the oxidising gas ozone. ${ }^{18}$ In contrast, oral supplementation with the antioxidant ascorbic acid in a dose sufficient to increase serum ascorbic acid concentrations by $63 \%$ had no effect on eNO.

There are several possible explanations for the effect of $\mathrm{NO}_{2}$ on eNO. A number of cytokine responses have been described soon after exposure to $\mathrm{NO}_{2}$. Blomberg et al found increased interleukin (IL)-8 in bronchial washings 1.5 hours after a 4 hour exposure to $\mathrm{NO}_{2}$ in a concentration of $2 \mathrm{ppm},{ }^{19}$ while increased IL-1, IL-6, IL-8 and GM-CSF, IL-8 and tumour necrosis factor (TNF) $\alpha$ production have been described in supernatant after in vitro exposure. ${ }^{2021}$ Such a mix of proinflammatory cytokines is likely to induce the NO producing enzyme nitric oxide synthase (NOS), although this process takes hours and cannot explain the decrease in eNO observed in this study.

Alternatively, $\mathrm{NO}_{2}$ may produce epithelial cell damage or dysfunction, in turn leading to reduced NO production. Devalia et al reported increased release of ${ }^{51} \mathrm{Cr}$ from prelabelled cells (implying cellular injury), attenuation of ciliary beat frequency, and increased movement of ${ }^{14} \mathrm{C}$-BSA across human bronchial epithelial cells in culture (again implying cellular injury) 1 hour after exposure to $\mathrm{NO}_{2}$ in concentrations ranging from 0.1 to $0.8 \mathrm{ppm}$ for 20 minutes. $^{22}$ It is unclear whether these changes are reversible. Transient epithelial cell damage from $\mathrm{NO}_{2}$ exposure could therefore explain our study findings.

There is another possible explanation for the reduction in eNO after $\mathrm{NO}_{2}$ exposure. As described in the introduction, the chemistry of the biologically relevant oxides of nitrogen is highly dependent on local redox conditions. ${ }^{2}$ $\mathrm{NO}$ is likely to react with molecules present in the fluid lining the airway lumen, including superoxide, thiol containing compounds such as glutathione and albumin (to form S-nitrosothiols), and oxygen, ${ }^{23}$ so that $\mathrm{NO}$ produced by epithelial cells is unlikely to diffuse entirely unhindered into the lumen. Rather, a complex interplay of reactions will occur and the end products will depend on local concentrations of these reactants. ${ }^{8} \mathrm{NO}_{2}$ will induce changes in this chemical milieu which are likely to impact on the local metabolism of NO.

$\mathrm{NO}_{2}$ undergoes reactive absorption in the ELF of the respiratory tract. The most important substrates for this reactive absorption are ascorbic acid and glutathione. ${ }^{9}{ }^{10}$ Both are sacrificial for $\mathrm{NO}_{2}$, although Kelly et al reported increased glutathione concentrations in bronchial washings 1.5 hours after a 4 hour exposure to $\mathrm{NO}_{2}$ (2 ppm), possibly reflecting active secretion of glutathione as a response to this high concentration oxidant insult. ${ }^{9}$ The reactive absorption of $\mathrm{NO}_{2}$ also leads to the formation of superoxide 1 hour after exposure. ${ }^{10}$ These complex changes in ELF redox state following exposure to $\mathrm{NO}_{2}$ may impact upon the diffusion of NO from epithelial cell to lumen in at least two ways: the increased availability of superoxide in the ELF could reduce the amount of $\mathrm{NO}$ appearing in the lumen through a reaction producing the cytotoxic product peroxynitrite, or the excess glutathione produced could lead to the formation of stable nitrosothiols. ${ }^{23}$ Thus, at least two redox sensitive reactions, both of which have been found to occur over appropriate time courses, could explain the observed decrease in eNO after $\mathrm{NO}_{2}$ exposure.

There is mounting evidence from other sources that ELF chemistry modulates eNO. Marshall and Stamler have suggested that the increased eNO levels observed in asthma may result from increased acidity in asthmatic airways $^{7}$ rather than from increased NOS induction as had been previously proposed. ${ }^{8}$ eNO levels are lower in chronic cigarette smokers than in non-smokers, ${ }^{24}{ }^{25}$ possibly as a result of the increased concentrations of glutathione and other antioxidants in their $\mathrm{ELF}^{26}$ eNO is lower in patients with cystic fibrosis, despite the increased NOS activity in the airways of this patient group, because NO is metabolised to nitrite in the ELF. ${ }^{6}$ Our laboratory has shown an increase in eNO levels minutes after exposure to cigarette smoke, ${ }^{27}$ probably mediated through the oxidant effect of the smoke on the ELF. ${ }^{28}$ More recently we have described an increase in eNO levels after exposure to D-arginine in steroid naive asthmatic subjects. Since L-arginine is the substrate for NOS, this effect cannot be mediated through NOS but is likely to represent a local chemical effect of the exposure. ${ }^{29}$ The results of the current study go further to suggest that alterations in airway chemistry can modulate eNO.

The finding that $\mathrm{NO}_{2}$ exposure reduces eNO levels may have further implications. Exposure to $\mathrm{NO}_{2}$ is known both to increase bronchial hyperresponsiveness and reduce ciliary activity. ${ }^{22}{ }^{30} \mathrm{NO}$ has been found to decrease smooth muscle hyperresponsiveness in the airways ${ }^{31} 32$ and has a role in the control of ciliary activity. ${ }^{33}$ Since we have demonstrated a decrease in eNO after exposure to $\mathrm{NO}_{2}$, it may be that the effects of $\mathrm{NO}_{2}$ on ciliary function and bronchial hyperresponsiveness are mediated through decreases in the bioavailability of NO, either by chemical consumption or secondary to epithelial cell damage or dysfunction. This possibility requires further investigation.

We found no effect of oral supplementation with ascorbic acid on eNO levels, despite increases in serum ascorbic acid concentrations of $63 \%$. Although dietary manipulation alters the ELF ascorbic acid concentration in guinea pigs, ${ }^{34}$ a similar effect has not been definitively demonstrated in humans. However, Mohsenin et al have described a protective effect of oral ascorbic acid (500 mg qds) on $\mathrm{NO}_{2}$ induced bronchial hyperresponsiveness in humans, ${ }^{35}$ suggesting that oral supplemental 
doses of ascorbic acid are able to reach the respiratory tract. Although ascorbic acid can modify the activity of NO in the systemic vasculature $^{45}$ and aids in the conversion of the $\mathrm{NO}$ metabolite nitrite back to $\mathrm{NO}$ in vitro, ${ }^{36}$ our results would suggest that ascorbic acid has no significant effect on the ELF metabolism of $\mathrm{NO}$ in vivo.

In summary, ascorbic acid supplementation for 2 weeks at a dose of $500 \mathrm{mg}$ twice daily does not affect eNO levels in healthy human subjects. On the other hand, exposure to $\mathrm{NO}_{2}$, $1.5 \mathrm{ppm}$ for 20 minutes, causes a small but statistically significant decrease in eNO levels. This observation provides a possible mechanistic link between exposure to $\mathrm{NO}_{2}$ and resulting bronchial hyperresponsiveness and decreased epithelial cell ciliary activity which requires further investigation.

The authors thank Quest Vitamins Ltd, Aston Science Park, UK for their support and for supplying both the ascorbic acid and placebo.

1 Barnes PJ, Liew FY. Nitric oxide and asthmatic inflammation. Immunol Today 1995;16:128-30.

2 Gaston B, Drazen JM, Loscalzo J, et al. The biology of nitrogen oxides in the airways. Am $\mathcal{F}$ Respir Crit Care Med 1994;149:538-51.

3 Palmer RM, Ferrige AG, Moncada S. Nitric oxide release accounts for the biological activity of endothelium-derived relaxing factor. Nature 1987;327:524-6.

4 Taddei S, Virdis A, Ghiadoni L, et al. Vitamin C improves endothelium-dependent vasodilation by restoring nitric oxide activity in essential hypertension. Circulation 1998; 97:2222-9.

$5 \mathrm{Xu}$ A, Vita JA, Keaney JF. Ascorbic acid and glutathione modulate the biological activity of S-nitrosoglutathione. Hypertension 2000;36:291-5.

6 Ho LP, Innes JA, Greening AP. Nitrite levels in breath condensate of patients with cystic fibrosis is elevated in contrast to exhaled nitric oxide. Thorax 1998;53:680-4.

7 Hunt JF, Kezhong F, Malik R, et al. Endogenous airway acidification. Implications for asthma pathophysiology. $\mathrm{Am}$ f Respir Crit Care Med 2000;161:694-9.

8 Marshall HE, Stamler JS. NO waiting to exhale in asthma. Am $\mathcal{F}$ Respir Crit Care Med 2000;161:685-7.

9 Kelly FJ, Blomberg A, Frew A, et al. Antioxidant kinetics in lung lavage fluid following exposure of humans to nitrogen lung lavage fluid following exposure of humans to nitroge

10 Velsor LW, Postlethwait EM. $\mathrm{NO}_{2}$ induced generation of extracellular reactive oxygen is mediated by epithelial lining layer antioxidants. Am ₹ Physiol 1997;273:L1265-75.

11 Tunnicliffe WS, Mark D, Harrison R, et al. A system for the generation of head-only delivery of submicronic particles for the study of the health effects of particulate air pollution. Eur Respir F 1998;12(Suppl 28):335s.

12 Levine M, Rumsey SC, Daruwala R, et al. Criteria and recommendations for dietary vitamin $\mathrm{C}$ intake. $\mathcal{F} A M A$ 1999;281:1415-23.

13 Levine M, Conry-Cantilena C, Wang Y. Vitamin C pharmacokinetics in healthy volunteers: evidence for a recommended dietary allowance. Proc Natl Acad Sci USA 1996;93:3704-9.

14 Bureau of Nutritional Sciences. A highly sensitive highperformance liquid chromatography method for the estimation of ascorbic and dehydroascorbic acid in tissues, biological fluids, and foods. Anal Biochem 1987;165:102-7.
15 Kharitonov S, Alving K, Barnes PJ. Exhaled and nasal nitric oxide measurements: recommendations. The European Respiratory Society Task Force. Eur Respir f 1997;10: 1683-93.

16 Silkoff PE. Recommendations for standardized procedures for the online and offline measurement of exhaled lower respiratory nitric oxide and nasal nitric oxide in adults and children 1999. Am f Respir Crit Care Med 1999;160:210417 .

17 Matthews JNS, Altman DG, Campbell MJ, et al. Analysis of serial measurements in medical research. BMF 1990;300: $230-5$.

18 Olin A-C, Stenfors N, Ljungkvist G, et al. Nitric oxide (NO) in exhaled air after ozone exposure. Eur Respir $\mathcal{F}$ 1998;12(Suppl 28):249s.

19 Blomberg A, Krishna MT, Bocchino V, et al. The inflammatory effects of $2 \mathrm{ppm} \mathrm{NO}_{2}$ on the airways of healthy subjects. Am f Respir Crit Care Med 1997;156:418-24, 2028 (published erratum)

20 Devalia JL, Campbell AM, Sapsford RJ. Effect of nitrogen dioxide on synthesis of inflammatory cytokines expressed by human bronchial cells in vitro. Am F Respir Cell Mol Biol 1993;9:271-8

21 Kienast K, McKinnon KP, Carter JD, et al. Nitrogen dioxide exposure of human airway epithelial cells in vitro increases steady-state concentrations of inflammatory mediator mRNAs. Am f Respir Crit Care Med 1995;151:A284.

22 Devalia JL, Sapsford RJ, Cundell DR, et al. Human bronchial epithelial cell dysfunction following in vitro exposure to nitrogen dioxide. Eur Respir f 1993;6:1308-16.

23 Stamler JS. Redox signaling: nitrosylation and related target interactions of nitric oxide. Cell 1994;78:931-6.

24 Fletcher TJ, Tunnicliffe WS, Chambers DC, et al. Nitric oxide in exhaled air of cigarette smokers. Thorax 1996; 51(Suppl 3):A18.

25 Kharitonov SA, Robbins RA, Yates D, et al. Acute and chronic effects of cigarette smoking on exhaled nitric oxide. Am 7 Respir Crit Care Med 1995;152:609-12.

26 Crissman KM, Slade R, Devlin R, et al. Effects of $\mathrm{NO}_{2}$ exposure on human bronchoalveolar lavage fluid antioxidants and other biochemical markers. Am $\mathcal{F}$ Respir Crit Care Med 1993;147:A444

27 Chambers DC, Tunnicliffe WS, Ayres JG. Acute inhalation of cigarette smoke increases lower respiratory tract nitric oxide concentrations. Thorax 1998;53:677-9.

28 Balint B, Donnelly LE, Hanazawa T, et al. Increased nitric oxide metabolites in exhaled breath condensate after exposure to tobacco smoke. Thorax 2001;56:456-61.

29 Chambers DC, Ayres JG. Effect of nebulised L- and $\mathrm{D}$-arginine on exhaled nitric oxide in steroid-naïve asthma. Thorax 2001;56:602-6.

30 Tunnicliffe WS, Burge PS, Ayres JG. Effect of domestic concentrations of nitrogen dioxide on airway responses to inhaled allergen in asthmatic patients. Lancet 1994;344: 1733-6.

31 Miura $M$, Yamauchi $H$, Ichinose $M$, et al. Impairment of neural nitric oxide-mediated relaxation after antigen exposure in guinea pig airways in vitro. Am $\mathcal{f}$ Respir Crit Care Med 1997;156:217-22

32 Silkoff PE, Sylvester JT, Permutt S. Modulation of baseline pulmonary function and airways responsiveness by endogenous NO in asthma. Am 7 Respir Crit Care Med 1999;159:A409.

33 Jain B, Rubinstein I, Robbins RA, et al. Modulation of airway epithelial cell ciliary beat frequency by nitric oxide. Biochem Biophys Res Commun 1993;191:83-8.

34 Dunster C, Kelly FJ. Dietary modulation of lung epithelial lining fluid vitamin C concentration. Respir Med 1994;88: 806-7.

35 Mohsenin V. Effect of vitamin $\mathrm{C}$ on $\mathrm{NO}_{2}$-induced airway hyperresponsiveness in normal subjects. A randomized double-blind experiment. Am Rev Respir Dis 1987;136: 1408-11.

36 Weitzberg E, Lundberg JO. Nonenzymatic nitric oxide production in humans. Nitric Oxide 1998;2:1-7. 